\title{
Effects on Nitrogen Kinetics in Sheep of the Supplementation of Sodium Propionate and Sodium Acetate to the Diet
}

\author{
Madoka Sutoh, Yoshiaki Obara and Susumu MiYamoto \\ Department of Animal Physiology, National Institute of \\ Animal Industry, Tsukuba Norin Kenky u danchi 305
}

(Received September 29, 1993)

\begin{abstract}
Three mature wethers fitted with rumen fistulas were used to investigate the effects on nitrogen kinetics of sodium propionate and sodium acetate added to their diet. The wethers were fed at 12 equal intervals daily in sequence on (1) crushed lucern hay cubes (basal diet) with sodium propionate, (2) basal diet only and (3) basal diet with sodium acetate. Supplemented energy as sodium propionate and sodium acetate were both $5.1 \%$ of gross energy in the basal diet. The isotope dilution method, with a single injection of $\left[{ }^{15} \mathrm{~N}\right]$ urea into blood and $\left[{ }^{15} \mathrm{~N}\right]$ ammonium chloride in to the rumen, was used to determine the metabolic rates of nitrogen in plasma urea and ruminal ammonia. When wethers were fed the diet with sodium propionate, the concentration and irreversible loss rate of ruminal ammonia significantly decreased relative to when they were fed the basal diet. The production rate of ruminal ammonia from dietary and endogeneous sources, except for urea, and nitrogen transfer rates from ruminal ammonia to plasma urea also decreased. The effect of supplementing sodium acetate to the diet on these kinetics of ruminal ammonia was smaller than that of sodium propionate. The concentration of plasma urea and urinary urea excretion significantly decreased when wethers were fed the diet with both VFA salts, though no clear change was observed in the transfer rate of plasma urea $\mathrm{N}$ into the digestive tract. The nitrogen excretion in urine was significantly reduced by the supplementation of both VFA salts, but nitrogen retention tended to increase only when wethers were fed the diet with sodium propionate. It is concluded that the supplementation of sodium propionate at the level used in this experiment decreased urinary urea excretion but did not affect urea recycling via the rumen. The smaller response of nitrogen kinetics to sodium acetate compared with sodium propionate would be associated with sodium acetate's weaker effect on ruminal ammonia production.
\end{abstract}

Anim. Sci. Technol. (Jpn.) 65(7) : 593-601, 1994

Key words : nitrogen kinetics, sodium propionate, sodium acetate, sheep

A ruminant has the ability to regenerate protein from its endogeneous urea via the incorporation of ammonia by ruminal bacteria. It has been found that urea recycling into the rumen is increased by the addition of rapidly fermentable carbohydrates to a herbage-based diet, which contributes to a reduction of nitrogen (N) excretion in urine ${ }^{7,11,14)}$. This increase in urea recycling, although the controlling mech- anism has remained uncertain, is associated with the change in production rates of some rumen fermentation end-products, such as carbon dioxide, ammonia and $\mathrm{VFA}^{13)}$. The effects of VFA were demonstrated in an experiment by NoRTon et al. ${ }^{11}$, who reported that butyrate infused in the rumen of sheep increased urea which was degraded in the rumen. On the other hand, an increase in the concen- 
tration of propionate was accompanied by the improvement of $\mathrm{N}$ retention which was induced by sucrose supplementation to the $\operatorname{diet}^{14)}$. WhrTELAW and $\mathrm{MLLNE}^{20)}$ reported that urea degradation in the digestive tract increased via the addition of mixed VFA, as well as butyrate. The object of this study was to ascertain the effects of propionate supplied as sodium salt into the rumen on the kinetics of $\mathrm{N}$ in urea and ammonia in sheep, and to compare such effect with those of acetate on equal energy.

\section{Materials and Methods}

Three wethers ( 4 years of age) fitted with ruminal fistulas were used. The wethers were adjusted to the basal diet ( $1380 \mathrm{~g} /$ day/wether) of lucerne hay cubes for 1 month before starting the experiment. Three experimental diets were offered to the wethers in sequence of (1) the basal diet with $69.2 \mathrm{~g} / \mathrm{day} /$ wether of sodium propionate (propionate diet), (2) the basal diet only and (3) the basal diet with 171.8 $\mathrm{g} / \mathrm{day} /$ wether of sodium acetate (acetate diet). The basal diet contained $35.3 \mathrm{~g}$ of $\mathrm{N}$ and 21.7 MJ of gross energy, which exceeded the maintenance level of NRC requirements ${ }^{13)}$ for ewes at the same body weight. The additional energy provided as either sodium propionate or sodium acetate was $1.11 \mathrm{MJ} /$ day/wether. Each feeding treatment was continued for 15 days. During the experiment, the wethers were kept in metabolic cages with automatic feeders and fed 12 times daily in equal quantities and at equal time intervals. Fresh water and a mineral salt block were available for ad libitum intake. Mean body weight (BW) of the wethers was $72 \pm 5.7$ and $73 \pm 7.1 \mathrm{~kg}$ at the start and at the end of the experiment, respectively.

On the 10th day of each treatment, a single intravenous injection of ${ }^{15} \mathrm{~N}$ labeled urea $(74 \mathrm{mg}$ ; 99 atom\%) dissolved in $10 \mathrm{ml}$ of sterile saline was made into each animal via the jugular vein. Samples of blood were then taken into heparinized tubes from the opposite jugular vein just before and at $0.5,1,1.5,2,3,5,7,9$ and $12 \mathrm{~h}$ after a tracer injection. A blood sample was chilled in ice and centrifuged to separate the plasma. Samples of ruminal fluid were taken through the fistulas using tubes covered with 200 mesh nylon sheet at the same intervals, measured for $\mathrm{pH}$ immediately, and subsampled as follows : $2 \mathrm{~m} l$ for osmotic pressure and VFA concentrations, and $10 \mathrm{ml}$ added with $5 \mathrm{ml}$ of $0.4 \mathrm{M}$ hydrochloric acids for the concentration and ${ }^{15} \mathrm{~N}$ enrichment of ammonia. On day 14, a single intraruminal infusion of ${ }^{15} \mathrm{~N}$ labeled ammonium chloride $(45 \mathrm{mg} ; 99$ atom $\%)$ and the complex of cobalt with ethylendiamine tetra-acetic acid (Co-EDTA ; $1.22 \mathrm{~g}$ ) dissolved in $50 \mathrm{~m} l$ of distilled water was made. Samples of plasma and ruminal fluid were taken in the same manner as described above. To separate the bacterial fractions, about $10 \mathrm{ml}$ of ruminal fluid were centrifuged at $100 \times \mathrm{g}$ for $1 \mathrm{~min}$ and then at $22,000 \times \mathrm{g}$ for $10 \mathrm{~min}^{6)}$. The bacterial fraction taken as the precipitate was freeze-dried and ground, and the supernatant was used for estimating Co concentration. For digestibility and $\mathrm{N}$ balance measurement, all feces and urine were collected for 3 days from day 11 to 13 of each dietary treatment. Feces samples were dried at $60^{\circ} \mathrm{C}$ and ground. Urine was collected and put in to $40 \mathrm{~m} l$ of $20 \%$ $(\mathrm{w} / \mathrm{v})$ sulfuric acid $\left(\mathrm{H}_{2} \mathrm{SO}_{4}\right)$ solution. Samples of plasma, ruminal fluid and urine were stored at $-20^{\circ} \mathrm{C}$ until later analysis.

Estimations of the concentration of VFA and ammonia in ruminal fluid and of glucose, urea and $\alpha$-amino $\mathrm{N}$ in plasma were conducted as described previously ${ }^{16)}$. The Co concentration and osmotic pressure in ruminal fluid were measured with an inductively coupled plasma spectrometer (Shimadzu Ltd., Kyoto) and by freezing-point depression with an osmometer (Advanced Instruments Inc., Mass.), respective1y. The nitrogen content, organic matter (OM) and NDF in the diet and feces, and the N content in the urine, were measured via the method of $\mathrm{AOAC}^{1)}$. 
To determine ${ }^{15} \mathrm{~N}$ enrichment, $\mathrm{N}$ in ruminal ammonia and plasma urea were isolated as ammonia and trapped into $1 \mathrm{~N}_{2} \mathrm{SO}_{4}$ by a method described previously $y^{17)}$. The ${ }^{15} \mathrm{~N}$ enrichment of these isolated samples and powdered bacterial fractions were measured with an automated nitrogen carbon analysis-mass spectrometer (Europa Scientific Ltd., Cheshire).

The volume and flow rate of ruminal fluid were determined from the decrease in Co concentration in ruminal fluid with time after infusion of CO-EDTA by a standard procedure ${ }^{3)}$.

Equations for lines describing the changes with time in the enrichment of ${ }^{15} \mathrm{~N}$ in pools of ruminal ammonia, ruminal bacteria and plasma urea were estimated with the aid of a computer programme. Irreversible loss rates and pool size with respect to the primary pool (i.e. pools into which isotopes were injected) and the proportion of $\mathrm{N}$ in any secondary pool (e.g. ruminal bacteria and plasma urea when isotopes were injected into the rumen) derived from a primary pool were calculated from the equation for curves by a standard procedure ${ }^{9)}$.

These results from the ${ }^{15} \mathrm{~N}$ tracer experiments were used to define a general two-pool open-compartment model of $\mathrm{N}$ flow into and out of plasma ures and ruminal ammonia pools (Fig. 1) using the procedure described by Nolan et al. ${ }^{10}$.

The data were analyzed, statistically based on the assumption that there were no systematic effects on the order in which the treatments were given. This assumption appeared reasonable, based on two facts. First, the wethers used in the experiment were mature and were fed indoors during the experiment. Second, in all metabolite concentrations measured here, the value of samples taken on day 9 of each treatment did not differ $(\mathrm{P}>0.25)$ from those taken on day 14. This indicated that the effects of prior treatment had disappeared by day 9 .

The effects of supplementation of VFA salts to the diet were compared using a paired, two-

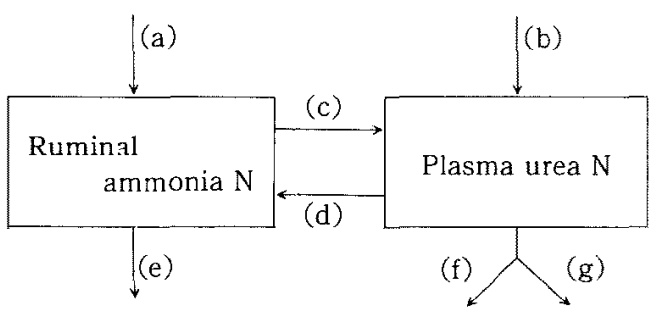

Fig. 1. A general two-pool, open-compertment model for $\mathrm{N}$ transactions associated with ruminal ammonia and plasma urea. The pathways of $\mathrm{N}$ flow represented in the model are often a composite of several pathways of transfer. The main components of these multiple pathways are: (a) ammonia $\mathrm{N}$ derived from dietary and endogeneous sources expect plasma urea, (b) urea $\mathrm{N}$ derived from (1) amino acids degraded in the body, but excluding microbial amino acids which were derived from ruminal ammonia and (2) ammonia absorbed from the lower digestive tract, (c) urea $\mathrm{N}$ derived from ammonia (1) absorbed from the forestomachs and (2) from digestion and metabolism of rumen microbial amino acids, (d) ammonia $\mathrm{N}$ derived from plasma urea which is transfered through the ruminal wall and as saliva, (e) ammonia $\mathrm{N}$ irreversibly lost as microbes, (f) urea $\mathrm{N}$ irreversibly lost into the lower digestive tract, $(\mathrm{g})$ urea $\mathrm{N}$ excreted in the urine.

tailed Student's $t$-test.

\section{Results}

Mean values for the major indices of fermentation and fluid kinetics in the rumen are shown in Table 1. A significant increase $(\mathrm{P}<$ $0.05)$ in the concentrations of acetate and propionate was observed when wethers were fed on the acetate diet and the propionate diet, respectively, compared with those when they were fed on the basal diet. The increase in total VFA concentration relative to that in the basal diet was significant $(\mathrm{P}<0.05)$ in wethers fed on the acetate diet, but not on the propionate diet. The concentrations of isobutyrate, isovaleriate and valeriate, not shown in the table, were not affected by dietary treatments. The ruminal $\mathrm{pH}$ tended to be higher in the propionate and acetate diets than in the 
Table 1. Effects of dietary supplementation of sodium propionate and sodium acetate on the major indices of rumen function in wethers

\begin{tabular}{|c|c|c|c|c|}
\hline & \multicolumn{3}{|c|}{ Treatments } & \multirow{2}{*}{$\begin{array}{l}\text { Treatment effect } \\
\text { and significancy } \\
\text { of difference }\end{array}$} \\
\hline & Basal diet & Propionate-diet & Acetate-diet & \\
\hline $\mathrm{pH}$ & $6.71 \pm 0.03$ & $6.87 \pm 0.06$ & $6.85 \pm 0.07$ & \\
\hline Total VFA concentration (mM) & $120 \pm 14$ & $125 \pm 11$ & $133 \pm 10$ & $\mathrm{BA}^{*}$ \\
\hline Acetate $(\mathrm{mM})$ & 78. $3 \pm 7.1$ & $77.3 \pm 9.4$ & $92.8 \pm 7.72$ & $\mathrm{BA}^{* *}$ \\
\hline Propionate (mM) & $25.9 \pm 2.5$ & $34.6 \pm 3.8$ & $24.6 \pm 2.3$ & $\mathrm{~PB}^{*}$ \\
\hline Butyrate (mM) & $11.0 \pm 1.0$ & $9.6 \pm 1.2$ & 10. $1 \pm 1.0$ & \\
\hline Osmotic pressure (mosmol/kg) & $266 \pm 32$ & $291 \pm 15$ & $308 \pm 14$ & $\mathrm{BA}^{*}$ \\
\hline Fluid volume (l) & $7.58 \pm 1.54$ & $7.55 \pm 2.12$ & $7.00 \pm 1.53$ & \\
\hline Fluid dilution rate $(\% / \mathrm{h})$ & $9.28 \pm 0.56$ & $9.72 \pm 0.53$ & $13.72 \pm 1.07$ & $\mathrm{BA}^{*}$ \\
\hline
\end{tabular}

Mean土standard deviation.

1) $\mathrm{BP}$, difference between the basal diet and propionate-diet; $\mathrm{BA}$, difference between the basal diet and acetate-diet; $\mathrm{PA}$, difference between propionate-diet and acetate-diet. ${ }^{*} \mathrm{P}<0.05,{ }^{* *} \mathrm{P}<0.01$

basal diet. Mean volumes of ruminal fluid did not differ between three dietary treatments, but the dilution rate was higher $(\mathrm{P}<0.05)$ in the acetate diet than in the basal diet.

Table 2 shows the concentrations of glucose, $\alpha$-amino $\mathrm{N}$ and urea- $\mathrm{N}$ in plasma and the indices of $\mathrm{N}$ kinetics in plasma urea and ruminal ammonia. Glucose and $\alpha$-amino $\mathrm{N}$ concentration in plasma were not altered $(\mathrm{P}>0.10)$ by the supplementation of both VFA salts. The concentration of plasma urea was lower $(\mathrm{P}<0.05)$ when wethers were fed a diet with both VFA salts rather than the basal diet. The pool size of urea also tended to be lower due to the supplementation of both VFA salts. The difference in the irreversible loss rate of plasma urea between three dietary treatments was not significant $(P>0.10)$, but the values for wethers with the propionate diet tended to be lower than those with the basal diet. The proportion of $\mathrm{N}$ in plasma urea derived from ruminal ammonia tended to be higher in the period of the propionate diet than in the basal diet. For ruminal ammonia, the concentration and pool size decreased when wethers were fed the propionate diet $(P<0.05$ and $P<0.10$, respectively) and the acetate diet $(\mathrm{P}<0.05)$ compared with those on the basal diet, but the difference in the irreversible loss rate was significant $(\mathrm{P}<0.05)$ only between the propionate diet and the basal diet. In the proportions of $\mathrm{N}$ in ruminal ammonia derived from plasma urea and in ruminal bacteria derived from ruminal ammonia, the differences were not significant $(P)$ $0.10)$ between the three dietary treatments.

Flow rates of $\mathrm{N}$ into and out of the plasma urea and ruminal ammonia pools are shown in Table 3. For plasma urea $\mathrm{N}$ in wethers with the propionate diet, the inflow rate from body tissues and the lower digestive tract, the transfer rate to ruminal ammonia and the irreversible outflow rate to the lower digestive tract were not different from those in the basal diet, while the excretion rate of urea $\mathrm{N}$ in urine tended to be lower. For ammonia $\mathrm{N}$, the supplementation of sodium propionate to the diet decreased the inflow rate from diet and endogeneous non-urea sources $(\mathrm{P}<0.05)$, and the transfer rate from ruminal ammonia to plasma urea $(\mathrm{P}<0.01)$ compared with those in the basal diet. The irreversible outflow rate to ruminal bacteria also decreased $(P<0.05)$ due to the supplementation of sodium propionate. When wethers were fed the acetate diet, the changes in the flow rates of $\mathrm{N}$ in urea and ammonia were similar to those for the propionate diet, though no significant differences were detected between the values for wethers 
VFA Salts and N Kinetics

Table 2. Effects of dietary supplementation of sodium propionate and sodium acetate on the concentrations of glucose, $\alpha$-amimo $\mathrm{N}$ and urea in plasma and some indices of $\mathrm{N}$ metabolism in plasma urea and ruminal ammonia in wethers

\begin{tabular}{|c|c|c|c|c|}
\hline & \multicolumn{3}{|c|}{ Treatments } & \multirow{2}{*}{$\begin{array}{l}\text { Treatment effect } \\
\text { and significancy } \\
\text { of difference }{ }^{1)}\end{array}$} \\
\hline & Basal diet & Propionate-diet & Acetate-diet & \\
\hline Plasma glucose $(\mathrm{mg} / \mathrm{l})$ & $456 \pm 21$ & $468 \pm 8$ & $442 \pm 19$ & \\
\hline Plasma $\alpha$-amino $\mathrm{N}(\mathrm{mg} / l)$ & $30.5 \pm 4.3$ & $28.8 \pm 4.7$ & $29.0 \pm 1.8$ & \\
\hline \multicolumn{5}{|l|}{ Plasma urea } \\
\hline Concentration $(\mathrm{mgN} / \mathrm{l})$ & $236 \pm 25$ & $209 \pm 21$ & $198 \pm 15$ & $\mathrm{BP}^{*}, \mathrm{BA}^{*}$ \\
\hline Pool size $(\mathrm{gN})$ & $5.83 \pm 0.51$ & $4.79 \pm 0.44$ & $4.93 \pm 0.63$ & \\
\hline Irreversible loss $(\mathrm{gN} / \mathrm{d})$ & $21.4 \pm 0.6$ & $20.2 \pm 1.4$ & $21.1 \pm 0.3$ & \\
\hline $\begin{array}{l}\text { Proportion of } \mathrm{N} \text { derived } \\
\text { from ruminal ammonia (\%) }\end{array}$ & $54.5 \pm 6.7$ & $48.0 \pm 8.6$ & $52.8 \pm 10.8$ & \\
\hline \multicolumn{5}{|l|}{ Ruminal ammonia } \\
\hline Concentration $(\mathrm{mgN} / \mathrm{l})$ & $236 \pm 18$ & $153 \pm 30$ & $169 \pm 7$ & $\mathrm{BP}^{*}, \mathrm{BA}^{*}$ \\
\hline Pool size $(\mathrm{gN})$ & $2.15 \pm 0.50$ & $1.11 \pm 0.09$ & $1.05 \pm 0.18$ & $\mathrm{BA}^{*}$ \\
\hline Irreversible loss $(\mathrm{gN} / \mathrm{d})$ & $21.7 \pm 0.4$ & $17.2 \pm 1.5$ & $19.0 \pm 1.8$ & $\mathrm{BP}^{*}$ \\
\hline $\begin{array}{l}\text { Proportion of } \mathrm{N} \text { derived } \\
\text { from plasma urea }(\%)\end{array}$ & $7.0 \pm 0.5$ & $7.9 \pm 0.9$ & $7.8 \pm 2.4$ & \\
\hline $\begin{array}{l}\text { Proportion of bacterial } \mathrm{N} \text { derived } \\
\text { from ruminal ammonia }(\%)\end{array}$ & $52.1 \pm 7.3$ & $48.6 \pm 4.9$ & $47.0 \pm 14.2$ & \\
\hline
\end{tabular}

Mean士standard deviation.

${ }^{1} \mathrm{BP}$, difference between the basal diet and propionate-diet; BA, difference between the basal diet and acetate-diet ; PA, difference between propionate-diet and acetate-diet. ${ }^{*} \mathrm{P}<0.05$

Table 3. Effects of dietary supplementation of sodium propionate and sodium acetate on the flow rates of $\mathrm{N}(\mathrm{gN} / \mathrm{d})$ into and out of the plasma urea and ruminal ammonia pools in wethers

\begin{tabular}{|c|c|c|c|c|c|}
\hline \multirow{2}{*}{$\begin{array}{l}\text { Pathway } \\
\text { of } \\
\mathrm{N} \text { flow }\end{array}$} & \multirow{2}{*}{ Main components ${ }^{2)}$} & \multicolumn{3}{|c|}{ Treatments } & \multirow{2}{*}{$\begin{array}{l}\text { Treatment effect } \\
\text { and significancy } \\
\text { of difference }{ }^{3)^{3}}\end{array}$} \\
\hline & & Basal diet & Propionate-diet & Acetate-diet & \\
\hline \multicolumn{6}{|c|}{ Plasma urea $\mathrm{N}$ pool } \\
\hline (b) & $\begin{array}{l}\text { from amino acids in body } \\
\text { tissues and ammonia } \\
\text { in lower digestive tract }\end{array}$ & $10.10 \pm 1.16$ & $10.93 \pm 1.82$ & $10.39 \pm 2.50$ & \\
\hline (c) & from ruminal ammonia & $12.18 \pm 1.85$ & 10. $10 \pm 1.96$ & $11.56 \pm 2.17$ & $\mathrm{BP}^{* *}$ \\
\hline (d) & to ruminal ammonia & $1.59 \pm 0.14$ & $1.42 \pm 0.29$ & $1.52 \pm 0.39$ & \\
\hline (f) & $\begin{array}{l}\text { to ammonia in lower } \\
\text { digestive tract }\end{array}$ & $0.56 \pm 0.63$ & $0.65 \pm 1.04$ & $1.03 \pm 0.51$ & \\
\hline (g) & to urinary urea & $20.13 \pm 0.82$ & $18.97 \pm 0.56$ & $19.40 \pm 0.48$ & $\mathrm{PA}^{*}$ \\
\hline \multicolumn{6}{|c|}{ Ruminal ammonia $\mathrm{N}$ pool } \\
\hline (a) & $\begin{array}{l}\text { from diet and other } \\
\text { non-urea } \mathrm{N}\end{array}$ & $20.94 \pm 0.37$ & 16. $48 \pm 1.46$ & $18.28 \pm 2.10$ & $\mathrm{BP}^{*}$ \\
\hline (e) & to ruminal bacteria & $10.34 \pm 0.16$ & $7.79 \pm 0.68$ & $8.24 \pm 0.35$ & $\mathrm{BP}^{*}$ \\
\hline
\end{tabular}

Meantstandard deviation.

1) The pathways shown in Fig. 1.

2) See Fig. 1 legend for details.

3) $\mathrm{BP}$, difference between the basal diet and propionate-diet; $\mathrm{BA}$, difference between the basal diet and acetate-diet; PA, difference between propionate-diet and acetate-diet. ${ }^{*} \mathrm{P}<0.05,{ }^{* *} \mathrm{P}<0.01$ 
on the acetate diet and on the basal diet. The difference between the propionate diet and the acetate diet was significant $(P<0.05)$ only for the excretion rate of urea $\mathrm{N}$ in urine.

The digestibility of OM and NDF and N balance in the three dietary treatments is given in Table 4. The excretion of OM, NDF and N in feces did not differ $(P>0.10)$ among the three dietary treatments. Although urinary $\mathrm{N}$ decreased $(\mathrm{P}<0.05)$ in wethers on the acetate and propionate diets relative to those on the basal diet, $\mathrm{N}$ retention showed a tendency to increase only in those on the propionate diet.

\section{Discussion}

From the estimation of $\mathrm{N}$ flow shown in Table 3 , the changes in $\mathrm{N}$ kinetics via sodium propionate supplementation observed here can be explained as the result of the decreased inflow rate; that is, the production rate of ruminal ammonia from diet and endogeneous non-urea sources which mainly consist of ruminal epitherial cells and mucoprotein in saliva. This reduction lowered ruminal ammonia concentration, and consequently decreased the rate of its transfer into plasma by passive diffusion. This in turn led to a reduction in the synthetic rate of urea from ruminal ammonia, while there was no clear change in that from other sources, which mainly consist of amino acids. The reduced synthetic rate of urea resulted in a lowering of plasma urea concentration and eventually a decrease in urinary urea excretion.

The effects of sodium acetate on $\mathrm{N}$ kinetics tended to be similar to those of sodium propionate, but were not significant. It may be results of a smaller reduction in the ammonia production rate caused by sodium acetate than that by sodium propionate. However, the difference in effect on $\mathrm{N}$ metabolism between these VFA salts was significant only for the rate of urea excretion.

The reduction in ammonia production from dietary and endogeneous non-urea sources brought about by the supplementation of VFA salts was considered to be caused by the change in ruminal microbes, especially the reduced number of protozoa. It has been reported that the intraruminal infusion of sodium acetate solution causes a depression of the concentration of rumen ciliates ${ }^{2}$. Most species of protozoa have been known to produce ammonia from protein or amino acids ${ }^{19}$, and in addition, HINO and RUSSELL ${ }^{5)}$ reported higher deaminase activity of protozoa relative

Table 4. Effects of dietary supplementation of sodium propionate and sodium acetate on the nitrogen balance and apparent digestibilities of OM and NDF in wethers

\begin{tabular}{|c|c|c|c|c|}
\hline & \multicolumn{3}{|c|}{ Treatments } & \multirow{2}{*}{$\begin{array}{l}\text { Treatment effec } \\
\text { and significancy } \\
\text { of difference }\end{array}$} \\
\hline & Basal diet & Propionate-diet & Acetate-diet & \\
\hline \multicolumn{5}{|l|}{ Noutput (gN/day) } \\
\hline Urinary $\mathrm{N}$ & $23.02 \pm 0.55$ & $20.84 \pm 0.96$ & $21.69 \pm 0.69$ & $\mathrm{~PB}^{*}, \mathrm{BA}^{* *}$ \\
\hline Fecal N & $8.42 \pm 0.18$ & $8.68 \pm 0.30$ & $9.07 \pm 0.36$ & \\
\hline $\mathrm{N}$ retention ( $\mathrm{gN} /$ day) & $3.09 \pm 0.71$ & $5.01 \pm 1.20$ & $3.77 \pm 0.50$ & \\
\hline \multicolumn{5}{|c|}{ Apparent digestibility (\%) } \\
\hline Nitrogen & $87.03 \pm 0.50$ & $86.35 \pm 0.88$ & $85.30 \pm 0.98$ & \\
\hline $\mathrm{OM}$ & $61.40 \pm 0.35$ & $61.03 \pm 0.57$ & $59.60 \pm 1.39$ & \\
\hline $\mathrm{NDF}$ & $44.46 \pm 1.05$ & $43.52 \pm 0.86$ & $41.75 \pm 1.53$ & \\
\hline
\end{tabular}

Mean \pm standard deviation.

1) $\mathrm{BP}$, difference between the basal diet and propionate-diet: $\mathrm{BA}$, difference between the basal diet and acetate-diet; PA, difference between propionate-diet and acetate-diet. ${ }^{*} \mathrm{P}<0.05,{ }^{* *} \mathrm{P}<0.01$ 
to bacteria. Therefore, the inhibitory effect of VFA on protozoa causes the decrease in ammonia production. Using a single intraruminal infusion of buffered VFA solution in cattle, KOBAYASHI and ITABASHI ${ }^{8)}$ demonstrated that propionate had a greater effect on the number of protozoa than acetate. This difference would explain the smaller change in ammonia production rate caused by sodium acetate than that by sodium propionate in the present study. The protozoa also contribute to fiber degradation in the rumen ${ }^{21)}$, though no significant difference was observed here in NDF digestibility between the three dietary treatments.

The increased production and absorption rate of ruminal VFA has been considered to promote the transfer of plasma urea into the rumen directly or via the effects on ruminal bacteria $^{13)}$. WHITELAW and MILNE ${ }^{20)}$ suggested that the additional energy itself was effective for urea degradation from their observation using sheep nourished wholly by intragastric infusion. However, no significant change in the rate of urea transfer was observed in the present study, in which $10 \mathrm{mmol} /$ day $/ \mathrm{kg}$ of BW of sodium propionate or sodium acetate were supplemented. In contrast, NORTON et $a l^{1 \mathrm{11}}$ infused about $11 \mathrm{mmol} / \mathrm{day} / \mathrm{kg}$ of $\mathrm{BW}$ of sodium butyrate into the rumen of sheep and reported a significant increase in the transfer rate of plasma urea into the rumen. The reason for this inconsistency is possibly connected with the energy level of the basal diet. The proportion of energy supplemented as the sodium salt of VFA was only $5 \%$ of that in the basal diet in the present experiment, while it was about $15 \%$ for NorTon etal. ${ }^{11}$, as mentioned above. The smaller proportion of the additional energy may lead to a smaller and undetected change in the rate of urea transfer.

Nitrogen retention tended to increase when wethers were fed the diet with sodium propionate rather than the basal diet (Table 4). In this treatment, the unchanged rate of fecal $\mathrm{N}$ excretion with the decreased production rate of ruminal ammonia would indicate an increase in the outflow rate of non-ammonia $\mathrm{N}$ from the rumen and then their absorption in the lower digestive tract. This elevated supply of non-ammonia $\mathrm{N}$ would mainly consist of undigested dietary protein, but not bacterial protein, since the rate of bacterial protein synthesis could be considered to decrease from the depression in the irreversible outflow rate of ammonia $\mathrm{N}$ to bacteria (Table 3 ), and with no change in the proportion of bacterial $\mathrm{N}$ derived from ammonia (Table 2).

The rate of amino acid supply into the lower digestive tract could be expected to increase also in wethers on the acetate diet from the decrease in ruminal ammonia concentration and the increase in the dilution rate of ruminal fluid (Table 1). However, $\mathrm{N}$ retention did not increase because of a small insignificant increase in fecal $\mathrm{N}$ output. This might be associated with another side of the effect of the increased dilution rate; that is, the reduction in the retention time of digesta and consequent reduction of amino acid absorption in the lower digestive tract. The lack of this change in dilution rate in wethers on the propionate diet would be partly explained by the amount of sodium $(16.6 \mathrm{~g}$ and $29.0 \mathrm{~g}$ of $\mathrm{Na} / \mathrm{day} /$ wether for the propionate and the acetate diet, respectively), which affects ruminal dynamics ${ }^{15)}$.

The supplementation of both VFA salts decreased total $\mathrm{N}$ and urea $\mathrm{N}$ excretion in urine, and the reduction was greater in the propionate diet than in the acetate diet. Given the $\mathrm{N}$ flow rate data, one of the reasons for this greater effect of sodium propionate is considered to be the stronger effect on the production rate of ruminal ammonia which accounted for half of all $\mathrm{N}$ sources of plasma urea. In addition, this would be connected with the promot ing effect of propinate on glucose kinetics, since it has been reported that the intravenous infusion of propionate reduced urinary $\mathrm{N}$ excretion as well as glucose, and more strongly 
than acetate ${ }^{4}$. In steers fed the diet with sodium propionate, VEENHUIZEN et al. ${ }^{18)}$ showed a trend toward decreased gluconeogenesis from sources other than ruminal propionate (possibly amino acids), with a significant increase in irreversible glucose loss. This suggests that the increase in propionate absorption may possibly promote $\mathrm{N}$ retention via saving the amino acids consumed for gluconeogenesis. This possibility could not be denied in the present study, although there was no change in $\mathrm{N}$ flow to plasma urea from sources including amino acids in the body. This route of $\mathrm{N}$ flow also includes the pathway from ammonia which is produced in and absorbed from the lower digestive tract. Therefore, it is possible that the decrease in the rate of deamination in the body was masked by the increase in ammonia production in the lower digestive tract, resulting from the increase in the inflow rate of amino acids. To estimate these two flows separately, a more detailed experiment with a three-pool system, including an ammonia pool in the lower digestive tract (mainly caecum), is needed.

\section{Acknowledgement}

We acknowledges Mr. K. Usul, Mr. Y. KOBAYASHI and Mr. Y. HASEGAWA for care of the experimental animals.

\section{References}

1) AOAC, Official methods of analyses. 13th ed. Association of Official Analytical Chemists. Washington, DC. 1980.

2) Borhami, B.E.A., K. EL-ShazLy and A.R. Abou AKKADA, Effect of ruminal infusion of acetatic acid and sodium acetate on the concentrations of ciliate protozoa. J. Agric. Sci., Camb., 78 : 239-244. 1972.

3) Downes A.M. and I.W. McDonald, The chromium-51 complex of ethylendiamine tetraacetic acid as a soluble rumen marker. Br. J. Nutr., $18: 153-162.1964$.

4) Eskeland, B., W.H. Pfander and R.L. Preston, Intravenous energy infusion in lambs : effects on nitrogen retention, plasma free amino acids and plasma urea nitrogen. Br. J. Nutr., 31 : 201-
211. 1974.

5) Hino, T. and J.B. Russel, Effect of reducingequivalent disposal and NADH/NAD on deamination of amino acids by intact rumen microorganisms and their cell extracts. Appl. Environ. Microbiol., 50 : 1368-1374. 1985.

6) Hutton, K., F.J. Bailey and E.F. Annison, Measurement of the bacterial nitrogen entering the duodenum of the ruminant using diaminopimelic acid as a marker. Br. J. Nutr., 25 : 165.1971.

7) KENNEDY, P.M., The effects of dietary sucrose and the concentrations of plasma urea and rumen ammonia on the degradation of urea in the gastrointestinal tract of cattle. Br. J. Nutr., 43 : 125-140. 1980.

8) Kobayashi, T. and H. Itabashi, Effects of Intra-ruminal VFA infusion on the protozoal population of the rumen. Bull. Nat. Inst. Anim. Ind., 44 : 47-54. 1986. (in Japanese)

9) NOLAN, J.V. and R.A. LENG, Isotope techniques for studying the dynamics of nitrogen metabolism in ruminants. Proc. Nutr. Soc., $33: 1-9$. 1974.

10) Nolan, J.V., B.W. Norton and R.A. Leng, Futher studies of dynamics of nitrogen metabolism in sheep. Br. J. Nutr., 35 : 127-147. 1976.

11) Norton, B.W., A.N. JANE and D.G. ARmStrong, The effects of intraruminal infusions of sodium bicarbonate, ammonium chloride and sodium butyrate on urea metabolism in sheep. Br. J. Nutr., 48 : 265-274. 1982.

12) NRC, Nutrient Requirements of Sheep. 6th ed. National Academy Press. Washington. DC. 1985.

13) Obara, Y., D.W. Dellow and J.V. Nolan, The influence of energy-rich supplements on nitrogen kinetics in ruminants. in Physiological Aspect of Digestion and Metabolism in Ruminants.(TSUDA, T., Y. SASAKI and R. KAWASHIMA, eds.). 515-539. Academic press. San Diego. 1990.

14) Obara Y. and D.W. Dellow, Effects of intraruminal infusion of urea, sucrose or urea plus sucrose on plasma urea and glucose kinetics in sheep fed chopped lucern hay. J. Agric. Sci., Camb., 121 : 125-130. 1993.

15) ROGERS, I.A. and C.L. DAvis, Effects of intraruminal infusion of mineral salts on volatile fatty acid production in steers fed high-grain and high-roughage diets. J. Dairy Sci, 65 : 953962. 1982.

16) Sutoh, M., Y. Obara and S. Miyamoto, The effect of feeding frequency and dietary sucrose 
on rumen fermentation, plasma metabolites and insulin in sheep. Anim. Sci. Technol. (Jpn.), 62 : 1120-1128. 1991.

17) Sutoh, M., Y. Obara and T. Yoneyama, The effects of feeding regimen and dietary sucrose supplementation on natural abundance of ${ }^{15} \mathrm{~N}$ in some components of ruminal fluid and plasma of sheep. J. Anim. Sci., $71: 226-231$. 1993.

18) VeEnhuizen, J.J., R.W. Russell and J.W. YounG, Kinetics of metabolism of glucose, propionate and $\mathrm{CO}_{2}$ in steers as affected by injecting phlorizin and feeding propionate. J. Nutr.,
$118: 1366-1375.1988$.

19) Wallace, R.J. and M.A. Cotta, Metabolism of nitrogen-containing compounds. in The Rumen Microbial Ecosystem (P.N. Hobson ed.). 217-249. Elsevier Science Publishing. NY. 1988.

20) Whitela., F.G. and J.S. Milne, Urea degradation in sheep nourished by intragastric infusion : effects of level and nature of energy input. Exp. Phisiol., 76 : 77-90. 1991.

21) Williams, A.G. and G.S. Coleman, The rumen protozoa. in The Rumen Microbial Ecosystem. (P.N. Hobson, ed.) 217-249. Elsevier Science Publishing. NY. 1988.

\title{
飼料へのプロピオン酸ナトリウムおよび酢酸ナトリウム 添加がメン羊の体内窒素動態に及ぼす影響
}

\author{
須藤まどか・小原嘉昭・宮本 進 \\ 農林水産省畜産式験場，茨城県筑波農林研究団地 305
}

\begin{abstract}
成メン羊 3 頭を用い,ルーサンヘイキューブを基砧飼料とし，その総エネルギー量の $5.1 \%$ に相当する プロピオン酸ナトリウム $(\mathrm{Na})$ あるいは酢酸 $\mathrm{Na}$ を添加して, ルーメン内環境, 窒素出納および ${ }^{15} \mathrm{~N}$ 卜 レーサー法による血踧中尿素態䇪素とルーメン内アンモ二ア態窒素の代謝速度を測定した. その結果, プロピオン酸 $\mathrm{Na}$ 添加によって、ルーメンアンモニアの濃度およびイリバーシブルロスの有意な低下 と、飼料および尿素以外の内因性窒素に由来するルーメンアンモ二ア生成抢よびルーメンアンモ二アか

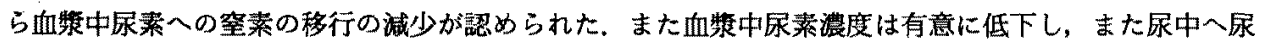
素わよび総空素排泄速度が低下して，体内窒素蓄積が增加する傾问にあった．しかし，血墏中尿素態空 素のルーメンアンモニアへの移行速度には変化が喼められなかった．以上のことから, 飼料へのプロピ オン酸 $\mathrm{Na}$ 添加は尿中尿素排泄の抑制によって室素蓄積を增加させるが，その原因の一つはルーメンで のアンモニア産生に対する抑制効果であり，本実験条件下においてはルーメン内への尿素リサイクル速 度には影響しないことが明らかになった，酢酸 $\mathrm{Na}$ 渿加の場合にも，窒素代謝の変化はほぼ同様の㑯向 を示したが，その変化はプロピオン酸 Na 添加の場合と比較して小さかった．これはルーメン微生物に よるアンモニア産生に対する影響が，プロピオン酸と比較して小さかったことが一因であると考えられ
\end{abstract} た.

日畜会報，65 (7)：593-601，1994 